\title{
Specific protective activity demonstrated in eggs of broodstock salmon injected with rabbit antibodies raised against a fish pathogen
}

\author{
Laura L. Brown ${ }^{1,2, *}$, Trevor P. T. Evelyn ${ }^{2}$, George K. Iwama ${ }^{1}$ \\ ${ }^{1}$ Department of Animal Science, Canadian Bacterial Diseases Network, University of British Columbia, \#248 - 2357 Main Mall, \\ Vancouver, British Columbia, Canada V6T 1 Z4 \\ ${ }^{2}$ Biological Sciences Branch, Department of Fisheries and Oceans, Pacific Biological Station, 3190 Hammond Bay Road, \\ Nanaimo, British Columbia, Canada V9R 5K6
}

\begin{abstract}
Many infectious disease agents affect salmonids early in life, long before the immune system of the fish is able to mount an efficient, protective response. This study was undertaken to determine if protective antibodies could be transferred to salmonid eggs and embryos by injecting the antibodies into female broodstock salmon prior to spawning. Resistance to Vibrio anguillarum (Va) was used as the model for this system because it is known that resistance to vibriosis is antibody-mediated. Antibodies raised against Va in rabbits were injected into female coho salmon Oncorhynchus kisutch before spawning and were detectable in the eggs by immunoassays. Fry from the injected broodstock were also challenged with Va following absorption of their yolk sac, but were not protected against Va. Contents of eggs from all broodstock (including saline-injected controls) were injected into naive coho fry, which were then challenged with live Va. Egg material from broodstock injected with rabbit anti$V a$ antibodies conferred protection against $V a_{\text {; }}$ in contrast, egg material from broodstock injected with saline did not. The results suggest that vertical transfer of mammalian antibodies can occur in salmonids; however, any conferred protection is not maintained for long after the yolk sac is absorbed. The findings described demonstrate a potentially useful new approach for passively immunizing large numbers of yolk sac larval salmonids against certain pathogens
\end{abstract}

KEY WORDS: Immunoglobulin - Salmonid eggs Vertical transmission Mammalian antibodies Maternal transfer

\section{INTRODUCTION}

Many pathogens cause disease in juvenile salmonids. Infectious haematopoietic necrosis virus (IHNV) and infectious pancreatic necrosis virus (IPNV), as examples, normally cause their greatest losses in salmonids during the early fry stages. Frequently these pathogens infect the young salmonids before the fish immune system is sufficiently mature to offer any significant specific protection. Indeed, some infectious agents such as IPNV (Wolf et al. 1963) and the kidney disease bacterium Renibacterium salmoninarum (Eve-

- Present address: National Research Council of Canada, Institute for Marine Biosciences, 1411 Oxford Street, Halifax. Nova Scotia, Canada B3H 3Z1. E-mail: laura.brown@nrc.ca lyn et al. 1984) can occur in eggs, and thus salmonids can be exposed to pathogens as early as the embryonic stage. Little is known of the possible mechanisms for protecting young salmonids from these and other pathogens. Furthermore, we do not have complete information concerning protective substances deposited by female salmon in their eggs that are transferable and protective to their offspring. Lysozyme levels are very high in freshly spawned salmonid eggs and the anti-microbial activity of the enzyme probably explains why only a limited number of bacterial pathogens are normally capable of vertical transmission (Yousif et al. 1994a). Presumably, the lysozyme also confers some protection in salmonid fry. Yousif et al. (1994b) also demonstrated the presence of lectin with antibacterial activity within freshly spawned sal- 
mon eggs. Other research has demonstrated the vertical transfer of immunoglobulin-like proteins in teleost species (Bly et al 1986, Shors \& Winston 1989, Mor \& Avtalion 1990, Hayman \& Lobb 1993). Passive transfer of protection (rather than simply the transfer of immunoglobulin-like proteins) from female broodstock salmon to their progeny has been suggested in some teleost species. Kawahara et al. (1993) have indicated that protection of charr Salvelinus leucomaenis against Aeromonas salmonicida was passively transferred from female broodstock that were actively immunized against the pathogen, and transfer of protective immunity has been demonstrated in tilapia Oreochromis aureus (Sin et al. 1994) and in rainbow trout Oncorhynchus mykiss (Oshima et al. 1996). In contrast, Liliehaug et al. (1996) vaccinated brood female Atlantic salmon Salmo salar against Yersinia ruckeri and, although they were able to detect specific agglutinating antibodies within the resulting eggs and posthatch fry, the authors found these low levels of salmonid antibodies were unable to protect the offspring against yersiniosis upon challenge.

The goals of this study were to determine whether female salmonids are capable of depositing externally derived (mammalian) antibodies in their eggs, and whether such antibodies would confer protection against an appropriate challenge on the fry hatching from such eggs. Antibodies raised against the bacterial fish pathogen Vibrio anguillarum (Va) were used. $V$. anguillarum is not normally an early life-stage pathogen of salmonids, but it is recognized that protection against Va in salmonids and other teleosts is mediated by humoral antibodies (Harrell et al. 1975, Viele et al. 1980, Groberg 1982, Aoki et al. 1984). The passive transfer of protective anti-Vibrio ordalii antibodies, both salmonid and mammalian was demonstrated by Velji et al. (1991), and thus the Vibrio model appeared suitable for our purposes.

Our experimental approach was to examine whether injecting female salmon with anti-Va antisera shortly before spawning resulted in the deposition of protective anti-Va antibodies in their eggs, and whether any protection was transferred to their progeny. Mammalian antibodies were used because mammals are more efficient antibody producers than salmonids and because large quantities of antibodies might be needed if the procedure proved sufficiently efficacious to warrant further examination.

\section{MATERIALS AND METHODS}

Bacteria. Vibrio anguillarum (Va, Pacific Biological Station strain R20, serovar O1) were grown at room temperature in aerated Brain. Heart Infusion broth
(Difco, USA) for $24 \mathrm{~h}$. Following incubation, formalin $[0.5 \%(\mathrm{v} / \mathrm{v})]$ was added to the culture. The culture flask was left at room temperature for at least $1 \mathrm{~h}$, to ensure complete killing of all bacteria. The cell suspension in broth was adjusted to ca $2 \times 10^{8}$ cells $\mathrm{ml}^{-1}$, corresponding to an absorbance of 5.0 at $420 \mathrm{~nm}$. This suspension was used for all immunizations and for all subsequent serum and egg adsorption steps.

Renibacterium salmoninarum (Rs) strain 384 (Pacific Biological Station, Nanaimo, BC, Canada) was grown, harvested, and formalin-killed as described elsewhere (Brown et al. 1996). Rs cells were used for serum and egg adsorption steps

Antibodies. Three New Zealand white rabbits were given a subcutaneous injection $\left(0.5 \mathrm{ml} \mathrm{kg} \mathrm{kg}^{-1}\right.$ animal weight) of the Va suspension diluted 1:1 with Freund's incomplete adjuvant. Four weeks later, the animals were given a second identical irjection. Two weeks later, the rabbits were given a third injection of the

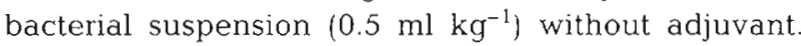
Ten days following the third injection the animals were terminally bled. The resulting sera were kept at $-80^{\circ} \mathrm{C}$.

The rabbit immunoglobulins were concentrated by precipitation with saturated ammonium sulfate (Harlow \& Lane 1988) as follows: sera from the 3 rabbits were pooled and centrifuged at $1700 \times g$ for $45 \mathrm{~min}$ to remove any debris. The supernatants were added to equal volumes of saturated ammonium sulfate and stirred overnight at $4^{\circ} \mathrm{C}$. The precipitates were then centrifuged at $1700 \times g$ for $45 \mathrm{~min}$, and the pellets were resuspended in phosphate buffered saline (PBS: $140 \mathrm{mM} \mathrm{NaCl}_{1} 8 \mathrm{mM} \mathrm{K}_{2} \mathrm{HPO}_{4}, 2.5 \mathrm{mM} \mathrm{KH}_{2} \mathrm{PO}_{4}$ ), at $1 / 10$ of the starting volumes, after which they were dialysed against 3 changes of PBS overnight at $4^{\circ} \mathrm{C}$. Protein concentration was determined (Lowry et al. 1951) using a commercially available test kit (Sigma, USA). The protein concentrations were adjusted to $50 \mathrm{mg} \mathrm{ml}^{-1}$ with PBS. The concentrated rabbit anti-Va antibodies (RAVA) were examined by polyacrylamide gel electrophoresis (PAGE).

Injection of broodstock. The RAVA preparation was injected (100 $\mathrm{mg}$ total protein per fish) into 6 wildcaught, mature female coho salmon Oncorhynchus kisutch, average weight $1.5 \mathrm{~kg}$, that were being held at a Department of Fisheries and Oceans Salmon Enhancement Hatchery, Capilano, North Vancouver, $\mathrm{BC}$, Canada. Six additional fish were injected with sterile saline as controls $\left(1.0 \mathrm{ml}\right.$ fish $\left.{ }^{1}\right)$. Passive integrated transponder (PIT) tags were inserted into the dorsal musculature of each fish for individual identification. The injection was given 11 to $26 \mathrm{~d}$ before spawning.

When ripe, the fish were manually spawned and the eggs collected and transported to the laboratory. Kidney samples were aseptically removed and examined 
by light microscopy and by culture to determine if $\mathrm{Va}$ was present. Samples of milt, for fertilization, were taken from male coho within the same stock as the injected females. Most of the eggs from each female were rinsed in sterile PBS and stored at $-80^{\circ} \mathrm{C}$.

Extraction of proteins from egg contents. For Western blot and PAGE analysis, proteins were extracted from the contents of the eggs of the injected broodstock following the method by Bade \& Stegemann (1984). Twenty eggs from each fish were thawed and pooled according to treatment group (at least 5 fish per group). Eggs were blotted on sterile filter paper to remove surface liquid, and content were removed aseptically from the eggs with $1 \mathrm{ml}$ syringes and disposable 25 gauge needles. Pre-cooled $\left(-20^{\circ} \mathrm{C}\right)$ isopropyl alcohol was added to the egg contents at a ratio of $1: 3$ (egg contents:alcohol) and mixed at $4{ }^{\circ} \mathrm{C}$ for $30 \mathrm{~min}$. The precipitated proteins were allowed to settle for $5 \mathrm{~min}$ before discarding the supernatant. This procedure was repeated 3 times with alcohol, and twice with pre-cooled acetone, in order to ensure complete removal of lipids. The final residue was collected in a Buchner funnel by washing with a small amount of acetone and then air-dried. The powder was stirred in PBS for $1 \mathrm{~h}$ at room temperature. Insoluble material was removed by centrifugation at $10000 \times g$ and the PBS-soluble egg extract (EE) stored at $4^{\circ} \mathrm{C}$.

Electrophoresis and Western blots of RAVA and egg extracts. RAVA and egg extract proteins were separated by SDS-PAGE (separating gels: $12 \%$ acrylamide, stacking gels: $6 \%$ acrylamide at $150 \mathrm{~V}$ for $45 \mathrm{~min}$ ), under denaturing conditions (with 2-mercaptoethanol) as outlined in Harlow \& Lane (1988). All steps were carried out at room temperature. After electrophoresis, proteins were electrophoretically transferred to a nitrocellulose (NC) membrane using a Mini-Blot apparatus (BioRad Laboratories) at $0.8 \mathrm{~mA} \mathrm{~cm}^{-1}$ for $1 \mathrm{~h}$. After blotting, the unreacted sites on the NC membrane were blocked with $3 \%(\mathrm{w} / \mathrm{v})$ gelatin in Tris-buffered saline (TBS: $20 \mathrm{mM}$ Tris, $500 \mathrm{mM} \mathrm{NaCl}, \mathrm{pH}$ 7.5). The $\mathrm{NC}$ membrane was incubated with gentle shaking overnight with the primary antibody (goat anti-rabbit IgG, Sigma). Primary antibodies were diluted 1:100 in antibody buffer [TBS containing $1 \%$ (w/v) gelatin] After washing, the NC membrane was incubated for $3 \mathrm{~h}$ with the secondary antibody [a biotinylated monoclonal antibody directed against goat IgG (Sigma)], diluted 1:200 in antibody buffer. A streptavidin-peroxidase solution diluted 1:200 in TBS was added, and the colour developed by adding 3,3'-diaminobenzidine tetrahydrochloride [DAB, $0.06 \%(\mathrm{w} / \mathrm{v})$ in TBS]

Challenge of the progeny of injected broodstock with Vibrio anguillarum. At spawning, about 200 eggs from each fish were fertilized, water-hardened and incubated in flowing water. The eggs from each fish were incubated separately and the progeny from all fish in a given treatment group pooled and then randomly divided into three $40 \mathrm{l}$ pot tanks (100 fish per group per tank) and acclimated to $13^{\circ} \mathrm{C}$. Two weeks after the fry were feeding (i.e. the yolk sac had been completely absorbed and the fry were relying solely on external food sources), they were all subjected to an immersion challenge with live Va cells. Briefly, Va was grown on Tryptic Soy Agar [TSA supplemented with $0.85 \%(w / v) \mathrm{NaCl}$ ] for $48 \mathrm{~h}$ at $15^{\circ} \mathrm{C}$ and the cells were removed aseptically and suspended in peptone-saline $\left[\mathrm{P} / \mathrm{S}_{\mathrm{i}} 0.1\right.$ to $\left.0.85 \% \mathrm{w} / \mathrm{v}\right]$. The suspension was adjusted to yield an absorbance of 2.5 at $420 \mathrm{~nm}$. The fish were netted and immersed for $15 \mathrm{~min}$ in $2 \mathrm{l} \mathrm{P} / \mathrm{S}$, with aeration, to which had been added enough bacterial suspension to give a final dose of $10^{5}$ cells $\mathrm{ml}^{-1}$. The fish were returned to their particular tank. After challenge, mortality was monitored for $13 \mathrm{~d}$. Mortality was determined as being due to vibriosis by examining at least $25 \%$ of all carcasses. Kidney samples were aseptically removed and smeared onto glass slides (for Gram staining) and onto $\mathrm{NaCl}$-supplemented TSA plates which were incubated at $15^{\circ} \mathrm{C}$ for at least $72 \mathrm{~h}$. Results were expressed as the mean cumulative percent mortality based on data from 3 replicate tanks per treatment group plus the standard error. The percent mortality at each time point for each treatment was compared to its appropriate control by means of the log-likelihood ratio or G-test (Sokal \& Rohlf 1981).

Passive transfer of immunity. One hundred eggs were taken from each group of injected broodstock (ca 20 eggs per fish), and the contents were removed aseptically with $1 \mathrm{ml}$ syringes and disposable 25 gauge needles and then pooled. Egg contents were diluted $1: 2,1: 9$, or $1: 49$ in PBS. In addition, aliquots of egg contents (diluted 1:1) were adsorbed with Va or Rs before injection into fry. A heavy Va or Rs suspension (absorbance $=5.0$ at $420 \mathrm{~nm}$ ) was added to samples at a 1:1 ratio. The mixture was incubated at $4^{\circ} \mathrm{C}$ for $1 \mathrm{~h}$, after which the cells were centrifuged and the pellet discarded. This adsorption step was repeated and the supernatant used for injection. The diluted or adsorbed, and non-adsorbed egg content samples were injected (0.1 ml per fish) intraperitoneal (i.p.) into naive coho salmon fry (ca 5 to $7 \mathrm{~g}$ each). The fish were kept in freshwater and had not been vaccinated against vibriosis. Additional groups of fry were injected with the RAVA (diluted to $1: 9$ in PBS) originally injected into the broodstock before spawning. Aliquots of the RAVA were also adsorbed with Va or Rs cells, and then injected into groups of fry, as above. Additional groups of fry were injected with sterile saline only $(100 \mu \mathrm{l}$ per fish), or were not injected (Table 1). To obviate tank effects and the need for replicate tanks, all injected fish were fin-clipped to distinguish the various treatment 
groups, 25 fish per group, and then pooled into a single tank. One day $(24 \mathrm{~h})$ after injection, the fry were subjected to an immersion challenge with live Va $\left(10^{5}\right.$ cells $\mathrm{ml}^{-1}$ for 15 min) as previously described. Water temperature was maintained at $12^{\circ} \mathrm{C}$. Mortality was monitored for $14 \mathrm{~d}$, and verified as being due to vibriosis.

\section{RESULTS}

\section{Evidence of previous Va infection within broodstock tissues}

There was no evidence of Va within any of the kidney taken from the injected broodstock, as examined by Gram stain and culture on $\mathrm{NaCl}$-supplemented TSA.

\section{Rabbit antibodies against Va are deposited in egg contents}

The dominant bands detected by antiserum against rabbit IgG in RAVA preparations are the ca $55 \mathrm{kDa}$ and $25 \mathrm{kDa}$ proteins characteristic of mammalian immunoglobulin heavy and light chains (Fig. 1A). These proteins are clearly detected in egg extracts (EE) from Group 1 (RAVA injected broodstock), as seen in
Fig. 1B, lanes 1 and 2, but are absent from Group 2 (saline-injected) EE samples (Fig. 1B, lane 3).

\section{Challenge of progeny of injected broodstock with Va}

When the progeny were challenged with live Va cells, there was a small (15\% units) but significantly higher $(p<0.05)$ mean cumulative percent mortality after $13 \mathrm{~d}$ (Fig. 2) among the progeny of broodstock injected with RAVA (Group 1), as compared with that obtained with progeny derived from the control broodstock (Group 2).

\section{Passive transfer of immunity}

There was a significant decrease $(p<0.01)$ in mortality due to vibriosis among fry injected with egg contents derived from RAVA-injected broodstock (Table 1 , treatments 1, 2, and 3) compared with fry injected with similarly diluted egg contents derived from the Group 2 (saline injected) broodstock fish (treatments 6 , 7 , and 8 ). There was also a significantly lower mortality experienced by the same fry (treatments 1, 2, and 3) than by the fry injected with saline only (treatment 14), or with fry that were fin-clipped only (no injection; treatment 15). This was most pronounced when the

Table 1. Material injected (i.p.) into coho fry for passive transfer of immunity. Fry were fin-clipped to denote treatment $(\mathrm{n}=25$ per treatment) and placed in a single tank following a bath challenge with Vibrio anguillarum (Va). Resulting mortalities (cumulative mortalities) were determined at $14 \mathrm{~d}$. Broodstock group: Group $1=$ injected with anti-Va rabbit antibodies (RAVA). Group $2=$ injected with saline only. Broodstock injections were given 11 to $26 \mathrm{~d}$ before spawning. Asterisk represents significant difference $(\cdots p<0.01$ or " $p<0.05)$ between mortalities experienced by a treatment group (fry injected with egg material from Group 1 broodstock or with RAVA) and the corresponding control group (fry injected with egg material from Group 2 broodstock, with saline, or not injected)

\begin{tabular}{|c|c|c|c|c|c|c|}
\hline Treatment & $\mathrm{Egg}^{\mathrm{a}}$ & Dilution ${ }^{b}$ & Adsorp. ${ }^{c}$ & RAVA $^{d}$ & Other ${ }^{e}$ & $\%$ Cum. mort \\
\hline 1 & Group 1 & $1 / 2$ & & & & $40^{\circ}$ \\
\hline 2 & Group 1 & $1 / 10$ & & & & $8 \cdots$ \\
\hline 3 & Group 1 & $1 / 50$ & & & & $10^{\circ}$ \\
\hline 4 & Group 1 & $1 / 2$ & Va & & & 100 \\
\hline 5 & Group 1 & $1 / 2$ & Rs & & & $32^{\bullet}$ \\
\hline 6 & Group 2 & $1 / 2$ & & & & 84 \\
\hline 7 & Group 2 & $1 / 10$ & & & & 84 \\
\hline 8 & Group 2 & $1 / 50$ & & & & 80 \\
\hline 9 & Group 2 & $1 / 2$ & Va & & & 90 \\
\hline 10 & Group 2 & $1 / 2$ & Rs & & & 100 \\
\hline 11 & & & & Rabbit & & $5^{\cdots}$ \\
\hline 12 & & & Va & Rabbit & & 60 \\
\hline 13 & & & Rs & Rabbit & & $5 \cdots$ \\
\hline 14 & & & & & Saline & 100 \\
\hline 15 & & & & & Not injected & 100 \\
\hline \multicolumn{7}{|c|}{ 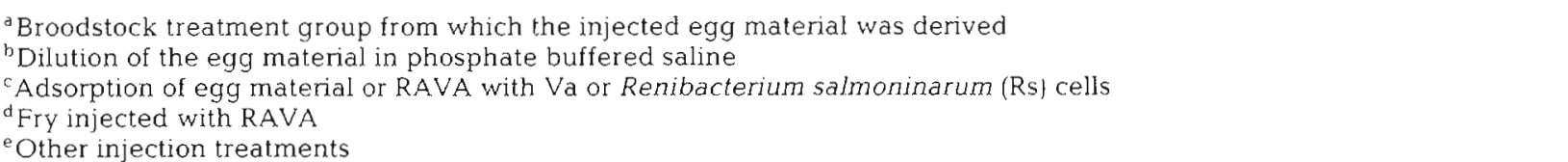 } \\
\hline
\end{tabular}




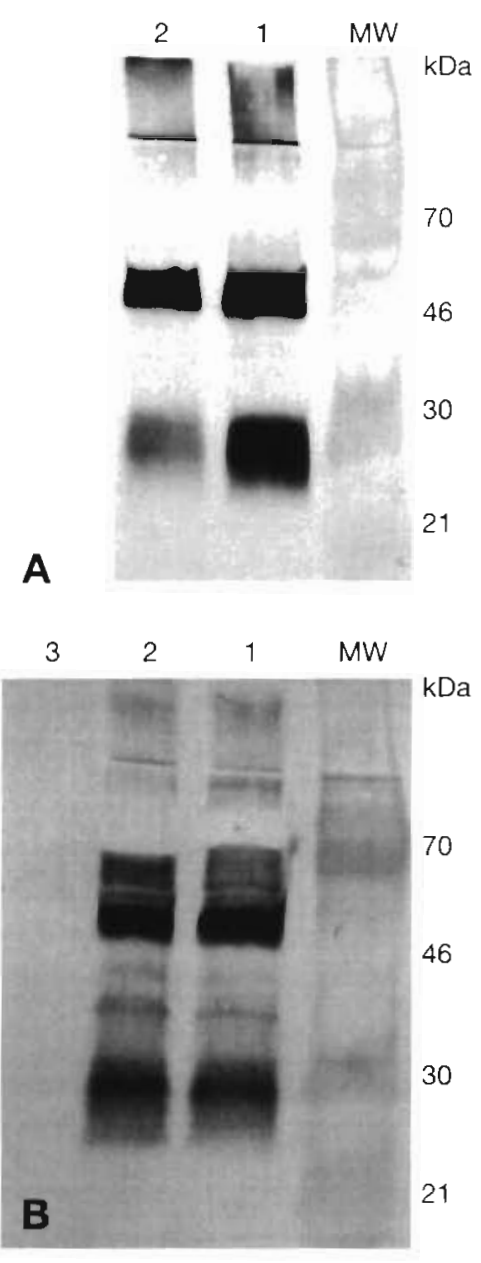

Fig. 1 (A) Western blot analysis of rabbit anti-Vibrio anguillarum antibody proteins (RAVA) concentrated by $\left(\mathrm{NH}_{4}\right)_{2} \mathrm{SO}_{4}$ precipitation. MW: Amersham Rainbow high molecular weight standards; Lane 1. $30 \mu \mathrm{g}$ RAVA; Lane 2: $15 \mu \mathrm{g}$ RAVA. (B) Western blot analysis of proteins extracted from the contents of eggs derived from injected broodstock. All sample lanes loaded with $25 \mathrm{\mu g}$ protein. MW: Amersham Rainbow high molecular weight standards. Lanes 1 \& 2: extracted egg contents from 2 fish injected with RAVA (Group 1). Lane 3: extracted egg contents from a fish injected with saline only (Group 2). All samples on both gels were run on a $12 \%$ SDS-polyacrylamide gel. Both blots were probed with polyclonal goat anti-rabbit IgG. Secondary antibody was a biotinylated monoclonal antibody against goat IgG

egg contents were diluted beyond 1:1 in PBS. In fact, 1:9 and 1:49 dilutions of egg contents from Group 1 broodstock gave significantly $(p<0.05)$ better protection than the 1:1 dilution (treatments 2 and 3 vs 1 ).

There was no significant difference in the mortality experienced by fry injected with egg contents from Group 2 (saline injected) and adsorbed with Va (treatment 9) or Rs (treatment 10) compared to fry injected with unadsorbed Group 2 egg contents (treatment 6). In contrast, there was a significant increase $(p<0.01)$ in mortality among fry injected with egg contents (treatment 4) from Group 1 adsorbed with Va cells, the homologous antigen, compared with that for fry injected with unadsorbed egg contents (treatment 1). There was no corresponding increase in mortality among the fry injected with the same egg contents adsorbed with Rs (treatment 5).

There was a significant decrease $(p<0.01)$ in mortality among the fry injected with the RAVA originally injected into the broodstock salmon (treatment 11). When this antiserum was adsorbed with homologous antigen (Va cells; treatment 12), there was a significant increase in mortality due to vibriosis; in contrast, when the antiserum was adsorbed with non-homologous antigen (Rs; treatment 13), there was no increase in mortality.

\section{DISCUSSION}

The results show mammalian antibodies injected into mature female coho salmon are transferred to their eggs (Fig. 1). The mammalian antibodies are active and capable of providing specific protection against a challenge with the homologous pathogen (Table 1). The passive transfer experiment was performed to demonstrate the functional presence of the antibodies found in the eggs (and assumed to be vertically transferred), and also to mimic the situation that might be expected to occur within developing alevins still in the 
process of absorbing their yolk sacs. Yolk sacs that contain appropriate protective immunoglobulins may therefore confer protection against pathogens that affect the embryo during early life stages. However, this type of protection apparently does not persist after the yolk has been absorbed, as revealed by the results of the challenge to the progeny of the injected broodstock (Fig. 2).

In the passive transfer experiment, the highest level of protection against Va was conferred by the highest dilutions tested (1:9 and 1:49) of the egg material containing the rabbit immunoglobulin (see Table 1). There are at least 2 possible explanations for this difference. First, the protective antibodies may not have been able to leach out of the concentrated egg proteins and lipids present in the 1:1 diiution rapidly enough to ensure maximum protection of the fry, whereas the more dilute mixture may have freed the clearly adequate amount of protective anti-Va antibodies present (as seen in the results shown in Table 1). Second, the fry may have been unduly stressed by an i.p. injection of a concentrated amount of egg protein and lipid, and may have compromised their ability to resist the Va challenge, despite the presence of the anti-Va antibodies. Whether this situation would be repeated in an alevin that was slowly absorbing its yolk sac is unknown. However, if this were the case, survival in alevins containing protective antibodies would still be expected to be considerably better than in alevins lacking the antibody. The data in Table 1 show antibodies in the most concentrated yolk material tested still reduced mortality significantly (from 100 to $40 \%$ ) on challenge.

The presence of specific mammalian immunoglobulins within the eggs is the most likely explanation for the protective effect seen in the passive transfer experiment. However, the possibility does exist that the RAVA injected into the Group 1 broodstock could have contained protective non-immunoglobulin proteins such as C-reactive or complement proteins that might have contributed to the observed protective effect. Non-specific acute-phase proteins (such as C-reactive proteins) do not persist long in an immunized animal (Mims 1990). The adsorption of egg contents with either Va or Rs cells was done in order to demonstrate the specificity of any protection conferred by the egg contents. Therefore, the results of the passive transfer of Va or Rs-adsorbed EE from the rabbit antiseruminjected broodstock suggest a high degree of specificity, normally associated with immunoglobulin molecules.

Because of limited availability of tanks, we were constrained to challenge the progeny of the injected broodstock at a stage past first-feeding only, rather than during the sac fry stage and at first feeding. Ideally, challenges should have been done at these stages also. The reason for the small (15\% units) but significant increase in mortality due to vibriosis among progeny of fish injected with rabbit anti-Va antiserum compared with progeny of control fish (Fig. 2) is unknown. However, despite the increase in mortality, the advantages that would be conferred by passive immune therapy for the young yolk-sac fry with mammalian antibodies against very early life-stage pathogens that have the potential to kill an entire stock (e.g. IHNV) would certainly outweigh the risk of later small losses due to the mammalian serum proteins.

The quantity of rabbit antibody proteins injected into the female broodstock was approximately the same size as that found in immunized salmonids, and was therefore a reasonable amount for these experiments. The dose of RAVA injected was calculated by extrapolation from previous studies to determine relative volumes of serum per fish weight, concentiation of serum protein within an immunized fish, and relative concentration of immunoglobulin to total serum protein (Evelyn 1971, Groberg et al. 1979, Ingram \& Alexander 1979, Iwama et al. 1986). The timing for injecting the brood fish was chosen based on our previous experience with incorporation of antibiotics into salmonid eggs via broodstock injection (Brown et al. 1990). The fact that rabbit immunoglobulin proteins were detected in the egg contents of the RAVA-injected fish indicates that this was an appropriate choice; however, this does not preclude the possibility that multiple injections, and/or injections at times earlier in oogenesis, would be as or more effective.

The results of this study indicate passive immunization of pre-spawning female salmon with mammalian antibodies has considerable potential as a means of protecting juvenile salmonids against pathogens that affect the fish at early life-stages, e.g. Flavobacterium psychrophilum, cause of coldwater disease, or viral pathogens, such as IPNV and IHNV. The protection would, however, be short-term, and probably would not extend beyond the yolk-sac stage. The technique holds promise as a means of preventing vertical transmission of salmonid pathogens. For example, it is conceivable that the vertical transmission of IPNV could be prevented with a pre-spawning injection of antiIPNV neutralising antibody raised in mammals. Also, it could prove of value in negating the adverse (tolerogenic) effects of molecules such as the Rs p57 molecule that may be deposited in eggs of Rs-infected fish (Brown et al. 1996). Using broodstock salmonids as the vehicle, it may be possible to entrain a wide range of molecules (e.g. molecules of pharmacological interest) into salmonid eggs. The mechanism by which proteins and other molecules [e.g. antibiotics (Brown et al. 1990)] are taken up by (or excluded from) salmonid eggs is a subject for further research. 
Acknowledgements. We thank Drs S. K. Balfry, R. Blaylock, Mr E. P. Groot, Dr S. C. Johnson, Mr J. E. Ketcheson, Mrs L. Prosperi-Porta, and Ms. E. Teng for their technical assistance. We are grateful to the personnel of the Canadian Department of Fisheries and Oceans Capilano River Salmon Enhancement Hatchery and Rosewall Creek Hatchery for donating their eggs, fish, and facilities and for their field assistance. We thank Dr M. Reith for critically reviewing the manuscript. L.L.B. was partly supported by a Science Council of British Columbia Graduate Research and Engineering Training scholarship. The project was funded, in part, by operating grants to G.K.I. from the Natural Sciences and Engineering Research Council of Canada and the Canadian Bacterial Diseases Network, National Centres of Excellence. Contribution no. NRC 39758

\section{LITERATURE CITED}

Aoki T, Sakai M, Takahashi S (1984) Protective immunity in ayu (Plecoglossus altivelis), vaccinated by immersion with Vibrio anguillarum. Fish Pathol 19:181-185

Bade H, Stegemann H (1984) Rapid method of extraction of antibodies from hen egg yolk. J Immunol Methods 72: $421-426$

Bly JE, Grimm AS, Morris IG (1986) Transfer of passive immunity from mother to young in teleost fish: hemagglutinating activity in the serum and eggs of plaice, Pleuronectes platessa. L. Comp Biochem Physiol 84A:309-313

Brown LL, Albright LJ, Evelyn TPT (1990) Control of vertical transmission of Renibacterium salmoninarum by injection of antibiotics into maturing female coho salmon Oncorhynchus kisutch. Dis Aquat Org 9:127-131

Brown LL, Iwama GK, Evelyn TPT (1996) The effect of early exposure of coho salmon (Oncorhynchus kisutch) eggs to the p57 protein of Renibacterium salmoninarum on the development of immunity to the pathogen. Fish \& Shellfish lmmunol 6:149-165

Evelyn TPT (1971) The agglutinin response in sockeye salmon vaccinated intraperitoneally with a heat-killed preparation of the bacterium responsible for the salmonid kidney disease. J Wildl Dis 7:328-335

Evelyn TPT, Prosperi-Porta L, Ketcheson JE (1984) The salmonid egg as a vector of the kidney disease bacterium, Renibacterium salmoninarum. In: ACUIGRUP (ed) Fish diseases. 4th COPRAQ Session Madrid, p 111-117

Groberg WJ (1982) Infection and the immune response induced by Vibrio anguillarum in juvenile coho salmon (Oncorhynchus kisutch). $\mathrm{PhD}$ thesis, Oregon State University, Corvallis

Groberg WJ, Voss EW, Fryer JL (1979) Metabolism of coho salmon Ig: intraperitoneal absorption properties of coho salmon tetrameric Ig. Fish Pathol 13:189-196

Harlow E, Lane D (1988) Antibodies-a laboratory manual. Cold Spring Harbor Laboratory, Cold Spring Harbor, NY

Harrell LW, Etlinger HM, Hodgins HO (1975) Humoral factors important in resistance of salmonid fish to bacterial disease. I. Serum antibody protection of rainbow trout (Salmo gairdneri) against vibriosis. Aquaculture 6:211-219
Hayman JR, Lobb CJ (1993) Immunoglobulin in the eggs of the channel catfish (Ictalurus punctatus). Dev Comp Immunol 17:241-248

Ingram GA, Alexander JB (1979) The immunoglobulin of the brown trout, Salmo trutta, and its concentration in the serum of antigen-stimulated and non-stimulated fish. J Fish Biol 14:249-260

Iwama GK, Greer Gl, Randall DJ (1986) Changes in selected haematological parameters in juvenile chinook salmon subjected to a bacterial challenge and a toxicant. J Fish Biol 28:563-572

Kawahara $E$, Inarimori $T$, Urano $K$, Nomura $S$, Takahashi $Y$ (1993) Transfer of maternal immunity of white-spotted char Salvelinus leucomaenis against furunculosis. Nippon Suisan Gakkaishi 59:567

Lillehaug A, Sevatdal S, Endal T (1996) Passive transfer of specific maternal immunity does not protect Atlantic salmon (Salmo salar L.) fry against yersiniosis. Fish \& Shellfish Immunol 6:521-535

Lowry OH, Rosebrough NJ, Farr AL, Randall RJ (1951) Protein measurement with the Folin phenol reagent. J Biol Chem 193:265-275

Mims CA (1990) The pathogenesis of infectious disease. Academic Press, London

Mor A, Avtalion RR (1990) Transfer of antibody activity from immunized mother to embryo in tilapias. J Fish Biol 37 : $249-255$

Oshima S, Hata J, Segawa C, Yamashita S (1996) Mother to fry, successful transfer of immunity against infectious haematopoietic necrosis virus infection in rainbow trout. J Gen Virol 77:2441-2445

Shors ST, Winston V (1989) Neutralizing antibodies for infectious haematopoietic necrosis virus in the eggs of steelhead trout (Salmo gairdnen). Am J Vet Res 50:232-234

Sin YM, Ling KH, Lam TJ (1994) Passive transfer of protective immunity against ichthyophthiriasis from vaccinated mother to fry in tilapias, Oreochromis aureus. Aquaculture 120:229-237

Sokal RS, Rohlf FJ (1981) Biometry. The principles and practice of statistics in biological research, 2nd edn. WH Freeman and Company, New York

Velji MI, Evelyn TPT, Albright LJ (1991) Nature of the immune response in coho salmon Oncorhynchus kisutch following vaccination with Vibrio ordalii lipopolysaccharide by two different routes. Dis Aquat Org 11:79-84

Viele D, Kerstetter TH, Sullivan J (1980) Adoptive transfer of immunity against Vibrio anguillarum in rainbow trout, Salmo gairdneri Richardson, vaccinated by the immersion method. J Fish Biol 17:379-386

Wolf K, Quimby MC, Bradford AD (1963) Egg-associated transmission of IPN virus of trouts. Virology 21:317-321

Yousif A, Albright LJ, Evelyn TPT (1994a) In vitro evidence for the antibacterial role of lysozyme in salmonid eggs. Dis Aquat Org 19:15-19

Yousif A, Albright LJ, Evelyn TPT (1994b) Purification and characterization of a galactose-specific lectin from the eggs of coho salmon Oncorhynchus kisutch and its interaction with bacterial fish pathogens. Dis Aquat Org 20: $127-136$

Submitted: January 13, 1997; Accepted: August 7, 1997 Proofs received from author(s): October 20, 1997
Editorial responsibility: David Bruno,

Aberdeen, Scotland, UK 